\title{
PREFERENCE ANALYSIS AND PURCHASING DECISION OF FRUIT CONSUMERS IN GENERATION Y (Case of Modern and Traditional Retail in Bogor)
}

\author{
Irpan Effendi ${ }^{*}$, , Mukhamad Najib ${ }^{2}$, Kirbrandoko ${ }^{3}$ \\ ${ }^{1}$ Master of Management and Business, Business School, IPB University, 16218 \\ ${ }^{2}$ Department of Management, Faculty of Economics and Management, IPB University, \\ Bogor, 16680 \\ ${ }^{3}$ Department of Management and Business, Faculty of Management and Business, IPB \\ University, Bogor, 16680 \\ *Corresponding author: effendiirfan56@yahoo.co.id
}

\begin{abstract}
Fruit is categorized as perishable product. Fruit trading still coordinated by direct sales, which consumers come over to the location then choose their own preference. Majority consumers prefer to go to the two shopping places for buying fruit products which is major in Indonesia or Bogor, for instance in modern retail or traditional retail. The issue in consumption character shifts caused by the generation alteration in which can influence business activities in the retail industry. At present, the traditional good retailers of modern generation $\mathrm{Y}$ is faced with different characteristics from the previous generation. Data was collected using questionnaires given to 150 respondents from the modern retail and 150 respondents traditional retail. The total questionnaires are 300 Generation Y respondents. The data was analyzed by descriptive analysis and Partial Least Square (PLS). The results indicated that the category in the modern retail the influence of the reference group and ethnocentrism had a positive effect and had the greatest influence on Y generation preferences as well as the categories in traditional retail reference groups and ethnocentrism had a positive and significant effect and product quality and prices have a negative effect on Y generation's preference for fruit shopping in modern retail. Meanwhile personal factors and places have a negative effect on Y generation's preference for fruit shopping in traditional retail. From modern and traditional fruit retailing consumer preferences have a positive and very significant effect on fruit purchasing decisions.
\end{abstract}

Keywords: ethnocentrism, generation $\mathrm{Y}$, preference, purchasing decisions, reference group

\begin{abstract}
Abstrak
Buah termasuk dalam kategori produk yang memiliki sifat mudah rusak. Penjualan buah masih didominasi oleh penjualan langsung, di mana konsumen datang ke lokasi dan kemudian terus memilihbuah yang akan di beli. Konsumen lebih menyukai pergi ke kedua kategori tempat belanja untuk produk buah-buahan yang umum di Indonesia atau Bogor, yaitu di ritel modern atau ritel tradisional. Data di peroleh dengan menggunakan Kuesioner yang diberikan kepada 150 responden konsumen buah dari ritel modern dan 150 responden konsumen buah dari ritel tradisional total kuesioner adalah 300 responden generasi Y. Pengolahan data menggunakan analsis deskriptif dan Partial
\end{abstract}


Least Square (PLS). Hasil penelitian menunjukan bahwa untuk kategori di ritel modern pengaruh kelompok acuan dan etnosentrisme berpengaruh positif dan memiliki pengaruh paling besar terhadap preferensi generasi Y sama halnya untuk kategori di ritel tradisional kelompok acuan dan etnosentrisme berpengaruh positif dan signifikan. Kualitas produk dan harga berpengaruh negatif terhadap preferensi generasi $\mathrm{Y}$ untuk berbelanja buah di ritel modern sedangkan faktor pribadi dan tempat berpengaruh negatif terhadap preferensi generasi Y untuk berbelanja buah di ritel tradisional. Dari ritel buah modern dan tradisional preferensi konsumen berpengaruh positif dan sangat signifikan terhadap keputusan pembelian Buah.

Kata kunci : etnosentrisme, generasi Y, preferensi, keputusan pembelian, kelompok acuan

\section{Introduction}

Retail is an important part of the product distribution process chain from producers to consumers. Thus, it can be said that the retail industry has a significant role to fulfill the individual, family and other end-user need. The retail industry in Indonesia contributes greatly to increasing Indonesia's Gross Domestic Product (GDP). As BPS (2017) states that Indonesia's GDP in agriculture, forestry and fisheries sector reach 15.39 percent in 2015, reach 13.39 percent in 2016 and 14.21 percent in 2017. Mining and excavation sector reach 10.08 in $2015,8.58$ percent in 2016 and 9.03 percent in 2017. Processing industry sector reach 25.41 percent in 2015, 22.33 percent in 2016 and 23.68 percent in 2017. Construction sector reach 11.55 percent in $2015,10.24$ percent in 2016, 10.88 percent in 2017. Large and retail trade sector reach 1.59 percent in 2015, 13.89 percent in 2016 and 14.71 percent 2017.

The tendency established was due to the increasing public demand for the fulfillment of consumer products. Retail products sold in the market are very diverse. Starting from basic needs, electronics, furniture, and fruits. It is known that fruit products have different characteristics from other products and very well-known of its main properties are perishable and volume. Fruit consumption in Indonesia is prominent to have decreased in its volume since it has lowest consumption level in Asia also Balitbang Kementan (2014) stated that orange, banana, durian and other commodities only consumed, it is known that in 2015-2016 the consumption of per capita fruit decreased significantly. This decline was identified in 3 categories of people's preference, namely oranges which decreased by 0.1 kilograms, bananas 0.2 kilograms and 1.6 kilograms.

Currently, both traditional and modern retailers grapple with the Millennials or Generation $\mathrm{Y}$ that have different traits and behaviors than the previous generation. According to Lancaster and Stillman (2010) there are large differences from generation $\mathrm{Y}$ that they tend to be more practical. The issue of changes in consumer character is the generations can also influence business activities in the retail industry. At present, both traditional and modern retailers confront the generation $\mathrm{Y}$ in which taken place of 34 percent of the total population of Indonesia. The distribution of generations in the city of Bogor in 2016 is very diverse, traditional generation components are 2 percent, baby boomers are 11 percent, generation $\mathrm{X}$ is 20 percent, generation $\mathrm{Y}$ is 34 percent and post millennial is 33 percent.

Moreover, it is known that currently the generation $\mathrm{Y}$ is recorded at 362,022 million or 34 percent in 2016 in Bogor. For the fruit trader in modern and traditional 
retailers, it can be an opportunity to work on segmentation in Generation $\mathrm{Y}$ that will become potential customers at present and in the future to be made a strategy for fruit retail business in Bogor and in Indonesia. This study was aim to determine the effect of personal factors, ethnocentrism, and reference groups that have a significant influence internally on Generation $\mathrm{Y}$ in fruit purchasing decisions, shopping, prices, and product quality to have a significant influence externally to generation $\mathrm{Y}$ in fruit purchasing decisions.

Research by Violetta (2018) entitled preference analysis and local fruit buying behavior on generation Y consumers. The results of the study show that ethnocentrism had a positive and significant effect on consumer preferences of the $\mathrm{Y}$ generation of local fruits. Research by Yanto (2006) states that the level of customer satisfaction can be proposed as a suitable retailing image strategy for Hypermart stores, namely increasing employee knowledge and performance, and maintaining employee friendliness or politeness and merchandise quality. Research by Anggasari (2013) entitled the influence of Ethnocentrism on attitudes, preferences, and behavior of buying local and imported fruit, used a survey with a descriptive design approach and crosssectional study. The results showed that there was a significant relationship between ethnocentrism with consumer preferences and purchasing behavior.

Research by Riska et al. (2012), entitled analysis of traditional market consumer preferences for local citrus fruits and imported citrus fruits in holy districts, aiming to examine the attributes of local citrus fruits and imported citrus fruits which are consumer preferences in holy districts, assessing attributes that most consumers consider in the decision to buy local citrus fruits and imported oranges in the holy district. The results showed that respondents who bought local and imported citrus fruits were dominated by women of productive age between 20-40 years, based on the attributes (taste, size, color, and aroma) in local citrus fruits and imported oranges. Local citrus fruit is a consumer preference which has a slightly sour sweetness, greenish yellow fruit color, medium fruit size (8-9 fruit/kg), and fresh fruit aroma. Whereas imported oranges which are consumer preferences are those that have a sweet orange color, medium size (8-9 pcs $/ \mathrm{kg})$, and fresh fruit aroma.

Research by Monecke and Leisch (2012) explaining PLS can be used more than 100 where this is proven from his research using 250 respondents. The next development plan is to improve the visualization method by making it more dynamic and more accessible to users to integrate simulator functions, and to draw samples from hypothetical models, thus it open the door to large-scale prediction experiments.

Retail series of business activities were increasing the value of goods and services sold to consumers is used as household final consumption (Levy \& Weitz, 2007). Kotler (2010) asserts that retail related to goods or services aimed at to the end consumers who are personal, not business. Retail is also interpreted as all business ventures that lead to marketing activities in order to satisfy end consumers who are at the core of distribution (Gilbert, 2003).

Retail businesses can be classified according to their shape, size, and level of comfort. In Presidential Regulation No. 112/2007 concerning structuring and fostering traditional markets, shopping centers and modern stores provide definitions of markets with self-service systems, selling various types of goods in retail in the form of minimarkets, supermarkets, department stores, Hypermarkets or wholesalers in the form of shipping.

This modern store limitation is emphasized in Article 3, in terms of sales floor 
area as follows: a) minimarket, less than $400 \mathrm{~m}^{2}$, b) supermarkets, $400 \mathrm{~m}^{2}$ up to 5,000 $\mathrm{m}^{2}$ c) Hypermarkets, above $5,000 \mathrm{~m}^{2} \mathrm{~d}$ ) department stores, above $400 \mathrm{~m}^{2}$; e) groceries, above $5,000 \mathrm{~m}^{2}$. Traditional market is built and managed by the government, local government, private sector, state-owned enterprises and regional owned enterprises including cooperation with the private sector, with the businesses, shops, kiosks, booths and tents owned or managed by small, medium, and independent traders community or cooperative with small-scale business, small capital and with the process of buying and selling merchandise through bargaining.

Lancaster and Stillman (2002) generation Y is a generation born in 1981-1999. Customer preferences is the attitude of customer who want an item or service based on their ability to influence their attitudes and behavior (Asri, 1990). Preference according to Kotler (1997) is the choice of likes or dislikes by someone towards the product (goods or services) consumed. Basically, preferences are dynamic, involving interaction and cognition and exchange of understanding, and consumer preferences, as for Kotler and Keller (2007) divided there are three dimensions of consumer, e.g. awareness dimensions which explain that consumers are aware of a good product, knowledge dimension defined consumers know and understand goods and services products, and liking dimensions elucidate that consumers like the product.

Purchasing decision can be achieved only if there are several alternatives. If there is no alternative choice then the action taken without the choice cannot be said to make a decision. According to Kotler and Armstrong (2010), consumer purchasing decisions is buy the most preferred brand from various alternatives, but two factors can be between purchasing intentions and purchasing decisions. The first factor is the attitude of others and the second factor is situational factors. Therefore, buying preferences and intentions do not always result in actual purchases. Kotler and Armstrong (2010) explain the dimensions of purchasing decisions including product selection, brand choice, distribution support selection and payment methods.

Personal factors are one of the factors that are included in the main factors that influence consumer behavior. Explained by Kotler (2010) personal factors is inherent in a person where they can be a source of influence on all of their purchasing activities. In personal factors, there are several important dimensions explained by Purnomohadi et al. (2012), namely the level of expectations, priorities, habits, tastes, emotions. Chang and Chien (2011) explain that ethnocentrism is a view of something where the group itself is the center of everything and otherwise measured and viewed by its group reference, each group fosters its own pride. The pride of them self as superior, glorifying and looking down on others group. Ethnocentrism is a positive and good attitude towards the culture that is owned (Endraswara, 2006). In ethnocentrism, marketing is often associated with buying products originating from a particular area (Shrimp \& Sharma, 1995).

A reference group is a group that is used as a view in shaping the values of attitudes and good behavior in general or specific (Engel et al., 1994). A reference group is a group that actually tries to influence and change the character of others (Sumarwan, 2014). In the process, the reference group will provide standards and values that can influence a person's behavior. In the marketing perspective, the reference group is often associated with purchasing decisions due to group influence.

Product quality is the overall feature of a product that affects the ability to satisfy expressed or implied needs (Kotler \& Armstrong, 2010). Arumsari (2012), explains that product quality is part of an item that gives in accordance with its basic 
purpose. Price is a sum of money issued by a person due to the exchange of products (Tjiptono, 2009). Kotler and Armstrong (2010) explain that price is money that is billed for transactions of products and services to customers from taking of these benefits. That is part of the marketing mix is a part that influences the distribution of product from producer to the consumer (Mursid, 2003). Kotler (2010) explains that place is the main part associated with the distribution of goods from producers to consumers.

This study aims to determine the effect of personal factors, ethnocentrism, and reference groups that have a significant influence internally on Generation $Y$ in fruit purchasing decisions, shopping, prices, and product quality to have a significant influence externally to generation $\mathrm{Y}$ in fruit purchasing decisions

\section{Research Hypothesis}

Hypothesis 1: The reference group has a significant influence on preference Hypothesis 2: Personal has a significant influence on preferences Hypothesis 3: Ethnocentrism has a significant influence on preference Hypothesis 4: Places have a significant influence on preferences Hypothesis 5: Service prices have a significant effect on preferences Hypothesis 6: Product quality has a significant influence on decisions Preference Hypothesis 7: Preference has a significant effect on purchasing decisions

\section{Methods}

Sample respondents who will be used as a source of information to answer the problem statement in this study are consumers who are in the age range of 19-38 years. This is based on the fact that at the age of 20-38 years fall into the category of generation $\mathrm{Y}$ or millennial generation and respondents who have made purchases in both types of retail. Determination of the number of respondents that information will be taken is based on, determination of the number of respondents to be retrieved information is based on the method of structural equational modeling analysis and follows the opinion of Hair et al (2010) 5-10 times the number of indicators of research so that the number of respondents sampled is 150 people, the calculation is as follows: (number of samples $=5$ to $10 \mathrm{X}$ indicators), number of samples $=5 \mathrm{X} 26$. The number of samples is 130 or rounded to $150 \times 2$ retail categories $=300$

The primary data is obtained through direct interviews with respondents who are assisted with questionnaires that have been prepared in advance. Secondary data is obtained from the data published by the Central Bureau of Statistic. The research was conducted at either traditional or modern fruit retailer located in Bogor. This research is a quantitative and descriptive type with an associative approach to see the factors that influence on fruit purchasing decisions and consumer preferences in shopping for fruit. According to Hadari (2003), descriptive methods are research methods that focus attention on the problems or phenomena that are actually at the time the research was conducted. Respondents used as a source of information to answer the problem formulation in this study used a purposive sampling, approach in which the criteria of respondents were eligible to be used as sources of information, the criteria included generation $\mathrm{Y}$ respondents who were in the age range of 20-38 years in both types of retail. 


\section{The analytical method}

The analytical method in this study uses two approaches, namely descriptive and intrinsic analysis. Descriptive analysis used in this study is presented in the form of tables and graphs, while intrinsic analysis in this study uses Partial Least Square-Path Modeling (PLS-PM) analysis methods. PLS-PM is a statistical method used for analysis of structural models using latent variables.

\section{Findings}

\section{Respondents' Characteristics}

The data of this study was taken 150 respondents for traditional retail and 150 respondents for modern retail. In addition, in the description of the respondent, it was also intended to determine the tendency of consumption of local and imported fruits. The respondents' characteristic of this study is presented in Table 1.

$\underline{\text { Table } 1 \text { Research descriptions }}$

\begin{tabular}{|c|c|c|c|}
\hline \multicolumn{2}{|l|}{ Category } & \multirow{2}{*}{$\begin{array}{l}\text { Modern } \\
40\end{array}$} & \multirow{2}{*}{$\begin{array}{l}\text { Traditional } \\
33\end{array}$} \\
\hline Gender & Man & & \\
\hline & Women & 110 & 117 \\
\hline \multirow[t]{3}{*}{ Age (years) } & $19-25$ & 14 & 12 \\
\hline & $25-31$ & 97 & 48 \\
\hline & $31-36$ & 39 & 90 \\
\hline \multirow[t]{2}{*}{ Marital status } & Married & 95 & 106 \\
\hline & Single & 55 & 44 \\
\hline \multirow[t]{5}{*}{ Last education } & Junior high school & 17 & 82 \\
\hline & High school & 63 & 56 \\
\hline & Diploma & 23 & 3 \\
\hline & Bachelor degree & 44 & 3 \\
\hline & Others & 3 & 6 \\
\hline \multirow[t]{5}{*}{ Work } & College student & 6 & 35 \\
\hline & Civil servants & 3 & 27 \\
\hline & Private employees & 96 & 9 \\
\hline & Entrepreneur & 23 & 58 \\
\hline & Others & 22 & 21 \\
\hline Budget for Household & $<$ IDR 1.000 .000 & 28 & 14 \\
\hline \multirow[t]{3}{*}{ Spending per Month } & IDR 1.000 .000 - IDR 2.000 .000 & 33 & 31 \\
\hline & IDR 2.000.000 - IDR 3.000.000 & 49 & 61 \\
\hline & > IDR 3.000 .000 & 40 & 44 \\
\hline \multicolumn{2}{|c|}{ Budget for Spending on $<$ IDR 50.000} & 39 & 40 \\
\hline Fruit Purchases per & IDR 50.000 - IDR 100.000 & 51 & 27 \\
\hline \multirow[t]{2}{*}{ Month } & IDR $100.000-$ IDR 200.000 & 42 & 82 \\
\hline & $>$ IDR 200.000 & 18 & 1 \\
\hline
\end{tabular}

Identification of the location for purchasing modern retail fruit and traditional retail is very important. This is useful as information related to alleged fruit purchasing decisions. At locations in traditional roadside fruit shop in Bogor City 36 Respondents, Traditional market fruit shop in Bogor City 109 Respondents and Fruit shop on the 
roadside of Bogor City 5 Respondents.

The majority of consumers who shop for traditional retail fruit choose to shop at fruit shops located in traditional markets. This is indicated by the presence of products or other commodities needed by consumers, so that they can do shopping activities without having to move too far from one location to another. In addition, it is also explained related to the location of fruit purchases in modern retailers

It is known that the majority of consumers who are respondents choose to shop at supermarkets with mixed commodities with a total of 95 respondents. This is because consumers have the same tendency in shopping activities. They prefer to shop for other commodities. While consumers who choose to shop at fruit supermarkets total 55 Respondent In addition, it is also explained the fruit products that are excellent in both modern retail and traditional retail Fruit that is superior in modern retail, namely banana 77 respondent, compared to oranges 55 respondents durian 5 respondent and the other 13 respondents for traditional retail namely bananas 72 respondents, Compared to oranges 37 respondents, Durian 20 respondents and the other 21 respondents. it is known that are excellent among modern retailers and traditional retailers have something in common. That the fruits the favorite fruit of consumer is banana.

\section{Test Validity and Reliability of Variables}

In testing validity used Average Variance Extracted (AVE). Besides composite reliability, it is used to provide reliability information. Presented in Table 2

Table 2 AVE and Composite Reliability

\begin{tabular}{llllr}
\hline \multirow{2}{*}{ Variables } & Modern & & Traditional & 1 \\
\cline { 2 - 4 } & Composite Reliability & AVE & $\begin{array}{l}\text { Composite } \\
\text { Reliability }\end{array}$ & AVE \\
\hline Ethnocentrism & 0.879 & 0.593 & 0.884 & 0.606 \\
Price & 0.832 & 0.628 & 0.841 & 0.730 \\
Inquiry Group & 0.837 & 0.565 & 0.801 & 0.506 \\
Decision_Purchase & 0.816 & 0.602 & 0.766 & 0.556 \\
Product Quality & 0.838 & 0.634 & 0.973 & 0.923 \\
Private & 0.806 & 0.514 & 1.000 & 1.000 \\
Place & 0.736 & 0.513 & 0.769 & 0.530 \\
Preference & 0.931 & 0.818 & 0.569 & 0.506 \\
\hline
\end{tabular}

The modern market has an AVE value that exceeds the normal limit (AVE $\geq 0.5$ ). On composite reliability values both in traditional retail and traditional retail have met the specified limit (composite reliability 70.7). In addition, composite reliability is the best parameter for reliability testing (Raykov \& Marcoulides, 2000).

\section{Test Validity of Indicators}

Testing the validity of an indicator is an outer test of the partial least square model. This is done to ensure that the indicators used are in accordance with the best recommendations for latent variables. Hair et al. (2010) explained that in testing the validity of the indicator is called convergent validity. An illustration of Table 3 is related to the Validity of Indicators. 
Table 3 Indicator validity

\begin{tabular}{llllll}
\hline Indicator & Modern & Traditional & Indicator & Modern & Traditional \\
\hline E1 & 0.859 & 0.726 & KP1 & 0.750 & 0.660 \\
E2 & 0.841 & 0.700 & KP2 & 0.831 & $\mathbf{0 . 0 6 5}$ \\
E3 & 0.723 & 0.753 & KP3 & 0.805 & 0.783 \\
E4 & 0.733 & 0.859 & P1 & 0.554 & $\mathbf{- 0 . 1 1 9}$ \\
E5 & 0.679 & 0.840 & P2 & 0.691 & 0.632 \\
H1 & 0.618 & $\mathbf{0 . 4 7 3}$ & P3 & 0.643 & $\mathbf{- 0 . 3 5 8}$ \\
H2 & 0.887 & 0.932 & P4 & $\mathbf{0 . 3 2 7}$ & 0.611 \\
H3 & 0.846 & 0.722 & P5 & 0.607 & $\mathbf{0 . 0 3 9}$ \\
KA1 & 0.821 & 0.775 & P6 & $\mathbf{0 . 4 6 6}$ & 0.652 \\
KA2 & 0.799 & 0.805 & PR1 & 0.810 & 0.807 \\
KA3 & 0.600 & 0.584 & PR2 & 0.574 & 0.610 \\
KA4 & 0.767 & 0.660 & PR3 & 0.770 & 0.657 \\
KEP1 & 0.842 & 0.743 & PR4 & 0.692 & 0.605 \\
KEP2 & 0.834 & 0.804 & T1 & 0.910 & $\mathbf{0 . 2 9 5}$ \\
KEP3 & 0.626 & 0.621 & T2 & 0.935 & $\mathbf{- 0 . 2 9 8}$ \\
KEP4 & $\mathbf{0 . 3 1 1}$ & $\mathbf{0 . 0 3 6}$ & T3 & 0.868 & 0.774 \\
\hline
\end{tabular}

\section{R-Square Research Model}

A quantity used to predict the variables in the model to describe the actual conditions. It is known in this study that there are two models, namely preferences and purchasing decisions. Data is presented as follows in Table 4.

Table 4 Modern Retail and Traditional Retail R-square

\begin{tabular}{lll}
\hline & Modern & Traditional \\
\hline Buying decision & 0.635 & 0.613 \\
Preference & 0.666 & 0.521 \\
\hline
\end{tabular}

Table 4 Suggestions about Preferences for objects of modern retail are higher than traditional retailers. Likewise in the purchase decision model, explain the value of modern retail is higher than traditional. On the other hand, the preference model in modern retailers is only able to explain 66.6 percent, while the remaining 33.4 percent is determined by factors outside the model. Likewise the model of purchasing decisions in modern retailers is only able to describe 63.5 percent is influenced by factors outside the model. Likewise, the model of purchasing decisions in modern retailers is only able to describe 63.5 percent and the remaining 36.5 percent is influenced by factors outside the model. In the traditional Model it can only be explained that the preference is only able to explain 52.1 percent and the purchasing decision model is only able to explain 61.3 percent.

Based on Figure 1 it is explained that R-square from a preference for objects of modern retail is higher than traditional retail. Likewise in the purchase decision model, explains that the value of modern retail is higher than traditional. On the other hand, the preference model in modern retailers is only able to explain 66.6 percent, where the remaining 33.4 percent is explained by factors outside the model. Likewise in the model of purchasing decisions in modern retailers, it is only able to draw 63.5 percent and the remaining 36.5 percent is influenced by the external factors. In traditional retail, it is known that the preference model is only able to explain 52.1 percent and the purchasing 
decision model is only able to explain 61.3 percent.

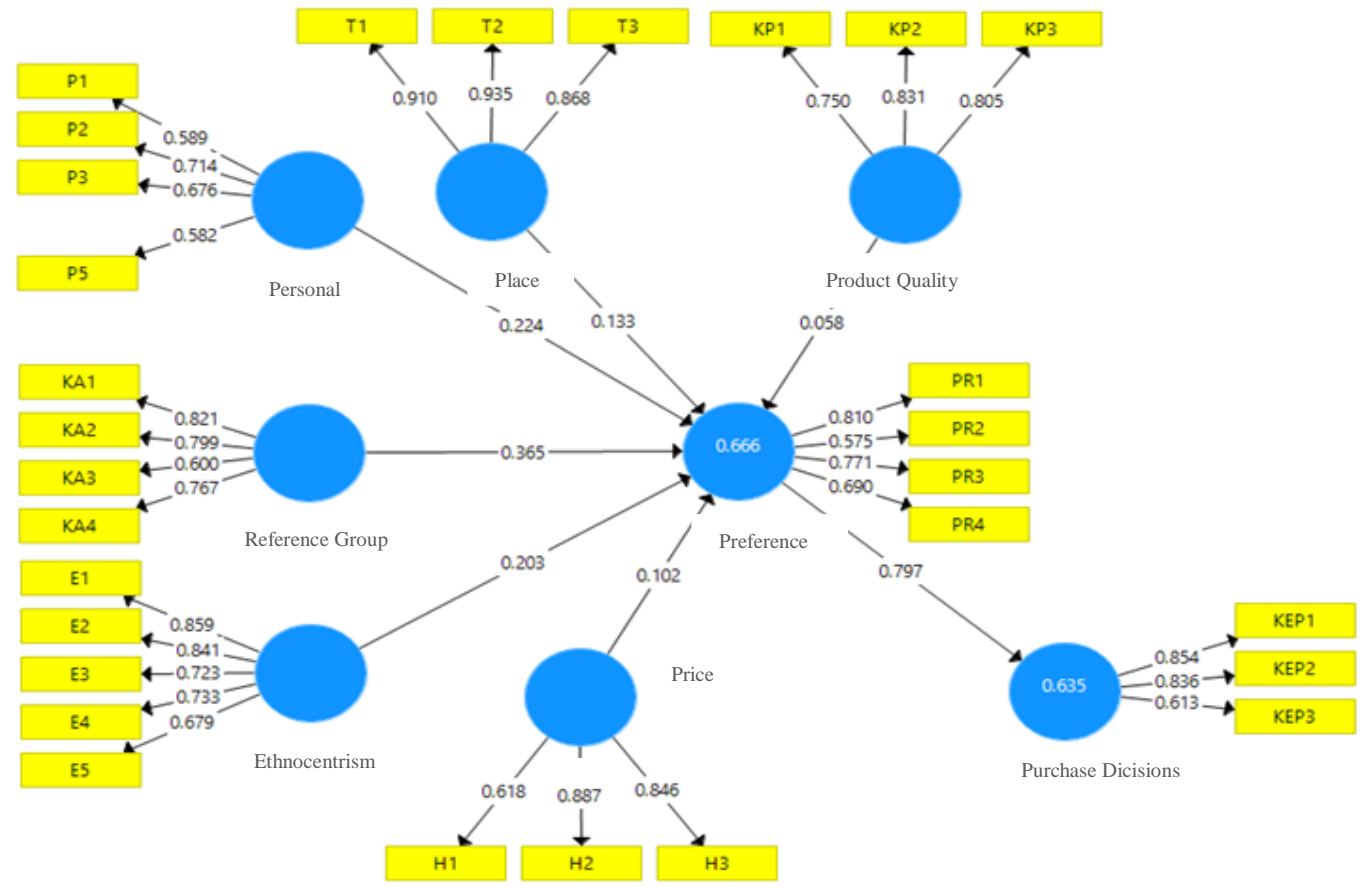

Figure 1 SEM-PLS Model Modern Retail

The results of data processing of consumer behavior in generation $\mathrm{Y}$ in traditional fruit retail are as follows

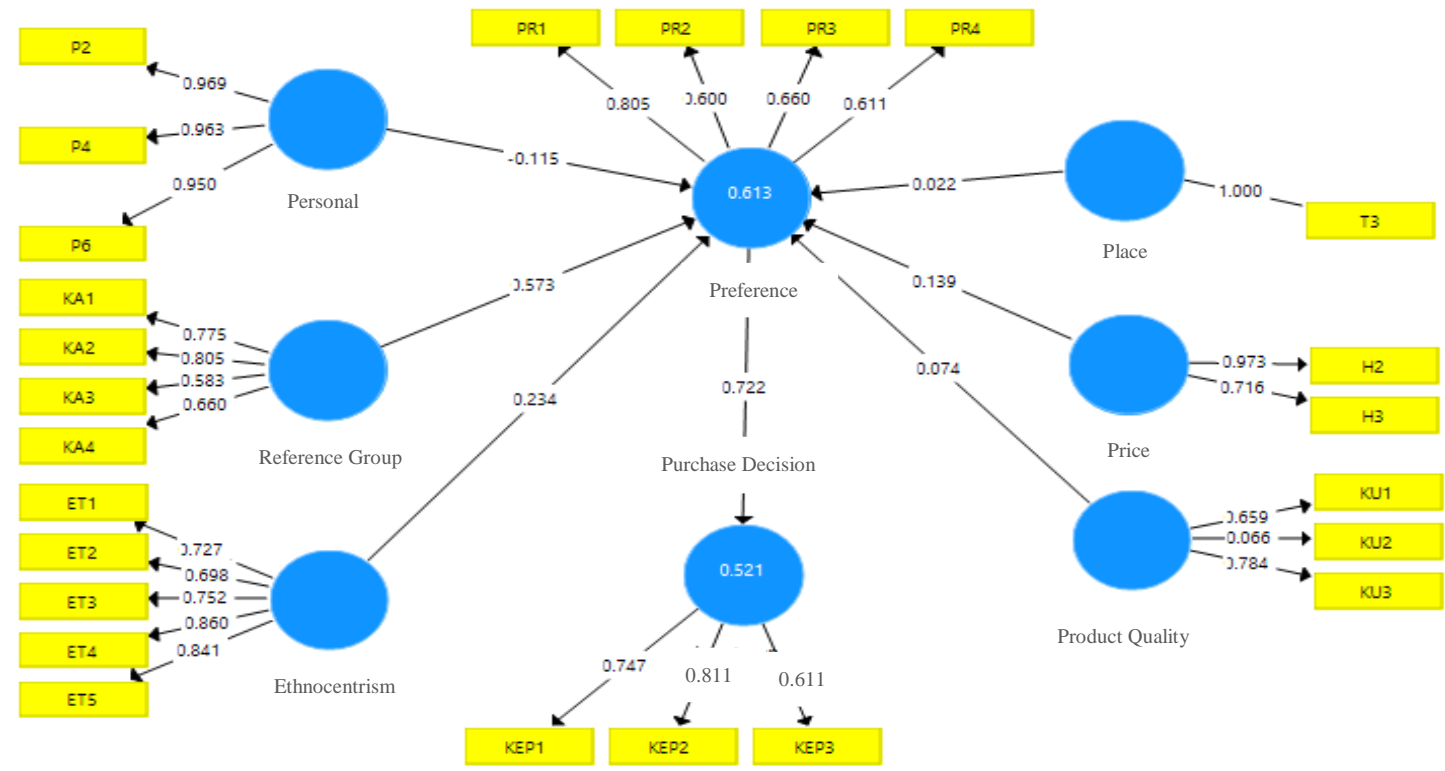

Figure 2 SEM-PLS Model Traditional Retail 
Table 5 Description of operational variables

\begin{tabular}{|c|c|c|}
\hline Variable & Symbol & Indicator \\
\hline \multirow{6}{*}{ Personal } & $\mathrm{P} 1$ & Expectations on the Quality of Fruit Products \\
\hline & $\mathrm{P} 2$ & Priority of Buying Fruits \\
\hline & P3 & Getting used to buying fruit \\
\hline & $\mathrm{P} 4$ & Get used to consuming fruit every day \\
\hline & P5 & Desire to Eat Mature Fruit \\
\hline & P6 & Fruit Consumption \\
\hline \multirow{4}{*}{ Reference group } & KA1 & Family Interest in Buying Fruits \\
\hline & KA2 & Advertisements Community Healthy Living Movement \\
\hline & KA3 & Interest in the fruits of the story of Relatives \\
\hline & KA4 & Effect of Fruit Consumption Trend \\
\hline \multirow{5}{*}{ Ethnocentrism } & E1 & Choose local fruit products from Indonesian farmers \\
\hline & E2 & Choice of Local Fruits \\
\hline & E3 & Priority of Buying Local Fruits \\
\hline & E4 & Concern for Indonesian Farmers Fruit Results \\
\hline & E5 & Responsible for the Love of Indonesian Farmers Fruit Results \\
\hline \multirow{3}{*}{ Place } & $\mathrm{T} 1$ & Public Road Access Towards Fruit Retail \\
\hline & $\mathrm{T} 2$ & Supporting Infrastructure towards Fruit Retail \\
\hline & $\mathrm{T} 3$ & Fruit Retail Locations That Are Easy To Visit \\
\hline \multirow{3}{*}{ Price } & H1 & Affordable Fruit Prices \\
\hline & $\mathrm{H} 2$ & Prices In Accordance With The Quality Of The Fruit \\
\hline & $\mathrm{H} 3$ & Competitive Fruit Prices \\
\hline \multirow{3}{*}{ Product Quality } & KP1 & Texture \\
\hline & KP2 & Product fragrant \\
\hline & KP3 & Product Appearance \\
\hline \multirow{4}{*}{ Preference } & PR1 & Consumption of Consumption of Fruits Good for the Body \\
\hline & PR2 & Know the Good Fruit Maturity \\
\hline & PR3 & Knowing the Information Benefits of Fruit Content \\
\hline & PR4 & Liked Fruit Products that are sold in the Retail \\
\hline \multirow{4}{*}{ Purchase decisions } & KEP1 & Choosing Fruits to be made as an additional meal \\
\hline & KEP2 & Choose a Local Fruit Brand \\
\hline & KEP3 & Buy fruit because there are other commodities \\
\hline & KEP4 & Liked E-Money Payments \\
\hline
\end{tabular}

\section{Loading Factor of Variables}

Testing of variables used in the study was conducted. Besides testing is done to determine the significance of each hypothesis determined. The hypotheses tested results from traditional and modern retail are presented in Table 6

Table 6 Hypotheses Testing

\begin{tabular}{lcccccc}
\hline \multirow{2}{*}{ Relationship } & \multicolumn{3}{c}{ Traditional } & \multicolumn{4}{c}{ Modern } \\
& Esti & T-stat & Info & Esti & T-stat & Info \\
\hline Ethnocentrism -> Preferences & 0.23 & 3.22 & Significant & 0.20 & 2.78 & Significant \\
\hline
\end{tabular}




\begin{tabular}{lcccccc}
\hline \multirow{2}{*}{ Relationship } & \multicolumn{3}{c}{ Traditional } & \multicolumn{4}{c}{ Modern } \\
& Esti & T-stat & Info & Esti & T-stat & Info \\
\hline Price -> Preferences & 0.13 & 2.12 & Significant & 0.10 & 1.54 & Not significant \\
Group Reference-> Preferences & 0.57 & 7.96 & Significant & 0.36 & 4.78 & Significant \\
Personal-> Preferences & -0.11 & 1.22 & Not significant & 0.22 & 3.35 & Significant \\
Place -> Preferences & 0.02 & 0.24 & Not significant & 0.13 & 2.56 & Significant \\
Product quality -> & 0.07 & 0.599 & Not significant & 0.05 & 1.07 & Not significant \\
Preferences & & & & & & \\
Preferences -> purchase decisions & 0.72 & 15.98 & Significant & 0.79 & 24.7 & Significant \\
\hline
\end{tabular}

The relationship of ethnocentrism variables to preference variables has the same results. The influence on traditional retail has a positive influence (0.234) and is significant with a value (3.228). This is because some consumers who buy fruit in traditional markets prioritize consuming local fruits rather than imports and realize to participate in supporting the welfare of Indonesian farmers when buying local fruit. In modern retail shows that the relationship is positive $(0.203)$ and significant with the value (2.786). This is because there are still many respondents who prioritize choosing to buy local fruits rather than imports in modern retailers and want to participate in bringing regional farmers into account when buying local fruit.

The relationship of the price variable to the preference variable has a result that is not the same for the object. Traditional retailers have a positive influence with a value (0.139) and a significant value (2.124). This is because consumers who shop for fruit in traditional retailers are very concerned about the price of fruit offered by sellers. While for modern retailers there is a positive influence with a value (0.102) but not significant with a value (1.544). In modern retailers, respondents who shop for fruit in modern retailers do not consider prices. This is due to the fact that when they shop for fruit in modern retailers there is more value to be paid for the shopping activities carried out.

The relationship of the reference group variable to the preference variable has the same result. Traditional retail has a positive influence with a value (0.573) and significance with a value (7.966). Consumer preferences in traditional retailers are caused by consumers actively socializing with primary and secondary groups. In addition, consumers who are subscribers to fruit sellers in traditional retailers are also caused by the influence of family or neighbors who promote word to mouth referring to a recommended activity for purchasing fruit from the merchant that affects the respondents' buying interest. In modern retailers, it is known to have a positive effect with a value of (0.365) and significant (4.786). This is because respondents who often shop to modern retailers are more critical and see primary and secondary reference groups and the existence of information related to the movement of the community to be more concerned about health.

The relationship of personal variables to preference variables has results that are not the same. In traditional retailers, it is known that the relationship between the two variables was declared not significant (1.225). This is because consumers are still not accustomed to consumption of fruit every day and respondents' expectations on fruit products sold in traditional retailers are still low for purchasing the desired fruit because there are still many fruits sold in traditional retailers that provide seasonal fruit. While in modern retail the relationship between the two variables has a positive effect with a value (0.224) and significant (3.350). This is due to the fact that most respondents are accustomed to consuming fruit. In addition, some consumers in purchasing fruit in modern retailers are in accordance with their desired tastes and are satisfied when 
consuming fruits sold in modern retailers.

Effect of place on preferences the relationship of the place variable to the preference variable has a different result. Traditional retailers have a positive influence with a value (0.022) but are not significant (0.240). This relationship is caused by consumers shopping for traditional retail fruit not paying too much attention to location conditions. This is exemplified by not questioning the access to roads and traditional retail infrastructure. While in modern retail, places have influence. While for modern retailers it has a positive influence with a value $(0.133)$ with a significant relationship. This is because consumers are very concerned about the conditions of access and supporting infrastructure, in another sense, describe through cleanliness and tidiness which is also related to consumer comfort.

Effect of product quality on preferences the relationship of product quality variables to preference variables has the same results. In traditional retail, it is known that the relationship between the two variables does not have a significant effect. This is because consumers believe that the quality of products sold by traditional retailers is still in the good category. This is evidenced by the activity of buying fruit, where consumers can choose the fruit they like themselves. Likewise, modern retailers have insignificant influence. This is because consumers are convinced that the products sold in modern retailers are of good quality and as expected.

Effect of preference on purchasing decisions the relationship of place variables to preference variables has the same results. At traditional retail, it is proven that the relationship between the two variables has a positive influence with a value $(0.722)$ and significant $(15,981)$. This is because consumers in traditional retailers are now starting to be dominated by consumers who are beginning to realize the importance of consuming fruit for health and knowledge of the benefits of fruit from the internet. In addition, modern retailers also have a significant influence (24.75). This has characteristics similar to those of traditional retail consumers but in modern retailers, it has advantages in a place that is better than traditional retail.

\section{Discussion}

Entrepreneurs who will have and will do the fruit business in traditional retailers and modern retailers need to pay attention to many things. For those who are interested in traditional retailing, it is highly recommended to pay attention to prices that are always competitive and maintain the availability of local fruits and always maintain good communication to improve service so that customers can recommend or promote business actors. On the other hand, employers also began to build communication with each buyer to get more influence from the reference group from consumers. For fruit entrepreneurs who are interested in the concept of modern retailing, they must focus on attractive locations, maintained product quality, availability of local fruits and building important groups. On the other hand, to improve purchasing decisions, entrepreneurs can integrate fruit products with other products. It is considered that it can influence the increase in fruit sales.

The government can begin to pay attention to the trends in consumer style. In this case, it is very clear that consumers are interested in local fruits due to many things. In addition, the government further promotes the dissemination of health programs in order to realize the importance of maintaining health by consuming fruit and increasing the volume of national fruit consumption. 


\section{Conclusion and Recommendation}

\section{Conclusion}

In this study, there were several important conclusions, including: Fruit retailing in Bogor City has two types, namely traditional retail and modern retail. Where in modern retail is divided into two forms, namely modern retailers that sell specialty fruit products and modern retailers that sell various kinds of the consumer must While in traditional retailers it is known that there are several types including traditional retail in the form of roadside stalls, mobile fruit sellers and fruit markets in traditional markets. Consumer preferences in traditional retailers and modern retailers are different. Where this is illustrated by several important factors that can influence consumer preferences. In the modern retail important factors are ethnocentrism, reference groups, personal and place, while in traditional retail, important factors are ethnocentrism, price, and reference groups. Consumer purchasing decisions, especially in the Y generation of modern and traditional retailers, are only able to describe no more than 60 percent. On the other hand, consumer purchasing decisions are very influenced by the good preferences of these consumers. In both types of retail preferences are known to have a positive and significant influence on fruit purchasing decisions in the city of Bogor

\section{Recommendation}

This study has several important suggestions, including: Growth in the number of people has an impact on increasing fruit consumption. Millennials who are already technology savvy want fast and practical services. Therefore, the entrepreneurs of fruit either modern retailers or traditional. Have to start to collect on consumers who buy fruit at their outlets. In addition, for traditional retailers, it is highly recommended to use the availability of online shipping services (online transportation services) technology in order to increase sales. For traditional retailers, they must start reading diverse consumer desires. One of them wants fruit that is always there and diverse. Therefore, it is highly recommended that traditional retailers diversify their products, so that fruit products are always available at any time according to the wishes of consumers. Basically, the millennial generation is very easy to make the location of purchase. Therefore the researcher suggests conducting further research on satisfaction and switching levels and switching out from purchasing fruit.

\section{References}

Badan Pusat Statistik. (2017). Ekonomi Indonesia Triwulan IV-2017 Tumbuh. Retrieved from: https://www.bps.go.id/pressrelease/2018/02/05/1519/ekonomi-indonesiatriwulan-iv-2017--tumbuh-5-19-persen.html

. (2016). Perpres No 112 Tahun 2007 UUD penataan dan pembinaan pasar tradisional pusat perbelanjaan dan toko modern. Retrieved from: http://www.bphn.go.id/data/documents/07pr112.pdf.

Anggasari, P. (2013). The effect of ethnocentrism on attitudes, preferences and buying behaviour of local fruits and imports (Bachelor's thesis). IPB University, Bogor, Indonesia.

Anoraga, B. J., \& Iriani, S. S. (2014). Influence of Lifestyle and Reference Group on 
Decisions of Purchasing Galaxy Brand Smartphone. Business and Management Journal 6(2), 139-147.

Arumsari. (2012). Effect of product quality on purchasing decisions. Sriwijaya State Polytechnic, Palembang, Indonesia.

Asri, M. (1990). Marketing ( $2^{\text {nd }}$ ed). Yogyakarta, Indonesia: BPFE University of Gajah mada.

Astari, H. (2013). Effect of value and lifestyle on behavioral preferences for purchasing Fruits Imported. Journal Family Sciences and Identification, 6(1), 39-46.

Badan Penelitian dan Pengembangan Kementrian Pertanian. (2014). Memperkuat Daya Saing Produk Pertanian. Jakarta, Indonesia: IAARD Press.

Badri, M. (2011). Coporate and Marketing Communication. Center for Communication and Business Studies at the Pasca Bachelor Program at Mercubuana University, Jakarta, Indonesia.

Chang, Yu-Hern Cheng, Chien-Hang. (2011). Exploring the effects of consumer ethics on preference for foreign airlines: A perspective of Chinese tourists. African Journal of Business Management, 5(34).

Durianto, D. Sugiarto. (2004). Strategies to Conquer the Market through Equity Research and Brand Behavior. Jakarta, Indonesia: PT. Gramedia Main Library.

Endraswara. (2006). Methods, Theories, Engineering, Cultural Research: Ideology, Epistemology and Applications. Yogyakarta, Indonesia: Widyatama Library.

Engel, J. F., G. Blackwell, Miniard, P. W. (1994). Perilaku Konsumen. Jakarta, Indonesia: Binarupa Aksara

Engel, James, F. (1994). Consumer Behavior in Consumer Behavior Book. Bogor, Indonesia: Binarupa Aksara Publisher.

Fandy. (2005). Marketing Services Poor. Malang, Indonesia: Bayumedia Publishing.

Gilbert, D. (2003). Retail marketing management. London, England: PrenticeHall

Hadari., N. (2003). Manajemen Sumber Daya Manusia untuk Bisnis yang Kompetitif. Yogyakarta, Indonesia: Gadjah Mada University Press.

Hair, J., F., Black, W., C., Babin, B., J., Anderson, R., E. (2010). Multivariate Data Analysis, Seventh Edition. London, England : Prentice Hall.

Harjadi, S., S. (1989). Basics of Horticulture. Department of Plant Cultivation, Faculty of Agriculture, Bogor, Indonesia: IPB University.

Howe, N. and Strauss, W. (2000). Millennials Rising: The Next Great Generation. New York, USA: Vintage Books.

Kotler, P., Keller. (2007). Manajemen Pemasaran, Jilid I, Edisi Kedua belas. Jakart, Indonesia: PT. Indeks

Kotler, P., \& Armstrong, G. (2010). Prinsip-Prinsip Pemasaran. Jakarta, Indonesia: Erlangga

Kotler, P. (2010). Marketing Management. Indonesian Edition Volume 1. Jakarta, Indonesia: PT Index

Kotler, P. (1997). Manajemen Pemasaran Analisis, Perencanaan, Implementasi, dan Kontrol. Jakarta, Indonesia: PT. Prehallindo

Lancaster, L. C. and Stillman, D. (2002). When Generations Collide. Who They Are. Why They Clash: How to Solve the Generational Puzzle at Work. New York, USA: Collins Business

Lancaster, L., C., Stillman, D. (2010). The m-factor: How the millennial generation is rocking the workplace. New York, USA: Harper Collins Publishers.

Levy, M., Weitz, B. (2007). Retailing Management. International Edition. New York, 
USA: McGraw-Hill.

Monecke, Leisch. (2012). SemPLS: Structural Equation Modeling Using Partial Least Squares. Journal of Statistical Software, 48(3), 1-32.

Mursid. (2003). Marketing Management. Issue 1. Jakarta Cooperate with the InterUniversity Center for Economic Studies UI, Jakarta, Indonesia: Bumi Aksara

Paul, J., Peter, Jerry, C., O. (2000). Consumer Behavior: Consumer Behavior and Marketing Strategy. Jakarta, Indonesia: Erlangga.

Purnomohadi, E., Sumarwan, U., Saefuddin, A., Eva, Z, Yusuf. 2012. Analisis Persepsi, Perilaku Konsumsi dan Preferensi Terhadap Pangan Tradisional. IPB University, Bogor, Indonesia.

Purnomohadi, E., Sumarwan, U., Saefuddin, A., Eva, Z,. Y. (2012). Perception Analysis, Consumer Behavior and Traditional Food Preferences. Journal Aplikasi Business and Manajemen, 3(2),1-13

Raykov, T. \& Marcoulides, G.A. (2000). A First Course in Structural Equation Modeling. New Jersey, USA : Lawrence Erlbaum Associates.

Riska, I.,Y., Mulya, S., Padmaningrum, D. (2012). Analysis of traditional market consumer preferences on local and imported citrus fruits in Kudus Regency. Agrista E-Journal, 1(2), 1-24.

Shrimp, T.A., \& Sharma, S. (1995). Consumer Ethnocentrism: A test of Antecedents and Moderators. Journal of the Academy of Marketing Science, 23(1), 26-37.

Stanton, William, J. (1998). Principles of Marketing Seventh Edition Volume 1. Jakarta, Indonesia: Erlangga

Sumarwan, U. (2014). Consumer Behavior Theory and Its Application in Marketing, Ghalia Indonesia. Bogor, Indonesia: IPB Press.

Sumarwan, U. (2014). Definition of Consumer Behavior. Second Edition Consumer Behavior Book. Bogor, Indonesia: Ghaila Indonesia.

Tjiptono. (2009). Service Marketing Strategy. Yogyakarta, Indonesia: CV Andi Yogyakarta Tjiptono.

Violetta, P., C. (2018). Analysis of Local Fruit preferences and buying behavior in $Y$ Generation Consumers (Bachelor's thesis). IPB University, Bogor, Indonesia.

Wiliam, J., S. (1998). Principles of Marketing Seventh Edition Volume 1. Jakarta, Indonesia : Erlangga.

Yanto, W. (2006). Analysis of Retailing Image on the level of customer satisfaction At hypermart Surabaya (thesis). Surabaya, Indonesia: Widya Mandala Catholic University Surabaya.

Zulkarnain. (2009). Basics of Horticulture. Jakarta, Indonesia: Earth Literacy. 